\title{
Tumour infiltrating lymphocytes: insights into tumour immunology and potential therapeutic implications
}

\author{
K F Yoong, D H Adams
}

Introduction

Although the interaction between the host immune system and cancer cells is still not fully understood certain clinical and experimental observations suggest that $\mathrm{T}$ cell mechanisms play an important role in anti-tumour immunity. In the clinical setting, spontaneous regression of some cases of malignant melanoma has been reported and these tumours are heavily infiltrated by lymphocytes. ${ }^{12}$ Furthermore, certain solid tumours which contain a high number of lymphocytes are associated with a better prognosis than those with less intense lymphocytic infiltration..$^{3-5}$ The increased incidence of many solid tumours in immunosuppressed hosts also supports the important role of cellular immunity in host defence against tumour growth. ${ }^{67}$ More recent studies of T cell receptor (TCR) $\alpha$ and $\beta$ variable gene expression have shown that $T$ cells infiltrating solid tumours are clonally expanded, suggesting that they have recognised antigens in the tumour environment, thus providing further evidence for the specificity of the anti-tumour response. ${ }^{8-10}$ Recent advances in cellular and molecular immunology have provided important insights into the complex mechanisms that regulate the immune response to tumours and have led to potentially exciting developments in cancer treatment. ${ }^{11}$ In this article we shall review the role of tumour infiltrating lymphocytes in the immune response against solid organ tumours and discuss the potential for their use in adoptive immunotherapy of cancer.

From LAK cells to cytokine activated TIL In 1976, interleukin-2 (IL-2) was shown to regulate the immune response by mediating the proliferation of antigen stimulated $T$ lymphocyte clones through both autocrine and paracrine loops. ${ }^{12}{ }^{13}$ The incubation of peripheral blood lymphocytes (PBL) or splenocytes with recombinant IL-2 generated effector cells which were capable of recognising and lysing autologous and allogeneic tumour cells in a non-MHC restricted fashion. ${ }^{14}{ }^{15}$ These lymphokine activated killer (LAK) cells were used as anti-tumour effector cells in adoptive immunotherapy and showed promise in several animal studies, but only limited response rates were obtained in clinical studies. Furthermore, the therapeutic efficacy of LAK cells was dependent on concomitant administration of high doses of recombinant IL-2, which was poorly tolerated and often associated with seri- ous toxicity related to increased capillary permeability and haemodynamic instability. In 1986, recombinant IL-2 was used to activate and expand lymphocytes from tumour tissue, tumour infiltrating lymphocytes (TIL), in the hope that these cells would show more potent and specific anti-tumour activity. ${ }^{16}{ }^{17}$ This review article highlights the important developments in TIL research that have taken place in recent years, particularly with regard to the molecular mechanisms that underlie their antitumour activity and to evaluate the therapeutic potential of TIL.

TIL are potent anti-tumour effector cells in animal models

TIL are a heterogenous population of mononuclear cells comprising mainly CD3+ $\mathrm{T}$ lymphocytes and, to a lesser degree, natural killer cells (NK) found in most solid tumour tissues (figs 1 and 2). TIL isolated from animal tumour models such as methylcholanthrene induced murine sarcoma are predominantly CD8+, and following a period of culture in a high concentration of exogenous IL-2, they acquire the ability to lyse specifically autologous tumour, but not normal, cells. ${ }^{18}$ In addition, they release specific cytokines such as interferon- $\gamma$ (INF- $\gamma$ ) and tumour necrosis factor- $\alpha$ (TNF- $\alpha$ ) when challenged with autologous tumour cells. ${ }^{19} 20$ These studies suggest that murine TIL recognise and respond to specific tumour antigens. Subsequent in vivo studies $^{16}$ showed that adoptively transferred TIL were effective in eradicating established three-day lung and liver micrometastases in murine sarcoma models and advanced tumours when used in conjunction with IL-2 and cyclophosphamide. In animal models, TIL seem to offer several therapeutic advantages over LAK cells; they are up to 100 times more potent as specific anti-tumour effector cells and could mediate the regression of LAK resistant tumours without the need for simultaneous administration of IL-2.

Isolation of TIL from human tumours

The impressive results from murine adoptive immunotherapy models provided the rationale for characterising human TIL with a view to utilising their anti-tumour activity in adoptive immunotherapy in humans. TIL have been isolated from a variety of human solid tumours including malignant melanoma, ${ }^{21}{ }^{22}$ renal cell carcinoma, ${ }^{23}$ ovarian malignancies, ${ }^{24}{ }^{25}$ colonic tumours, ${ }^{26}$ breast carcinoma, ${ }^{27}$ lung cancer, ${ }^{28}$
Correspondence to:

Accepted for publication 18 July 1996 


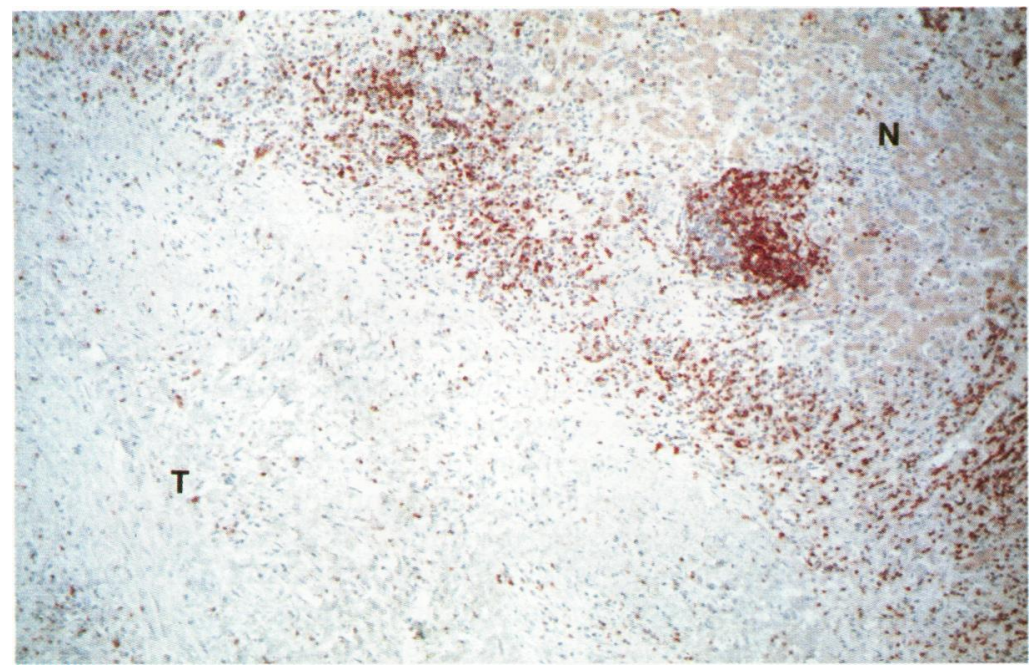

Figure 1 A section of human primary hepatocellular carcinoma stained with anti-CD3 monoclonal antibody and developed with alkaline phosphatase-anti-alkaline phosphatase complex and fast red. $C D 3+T$ cells are stained red. $N=$ non-tumoral liver tissue; $T=$ tumour.

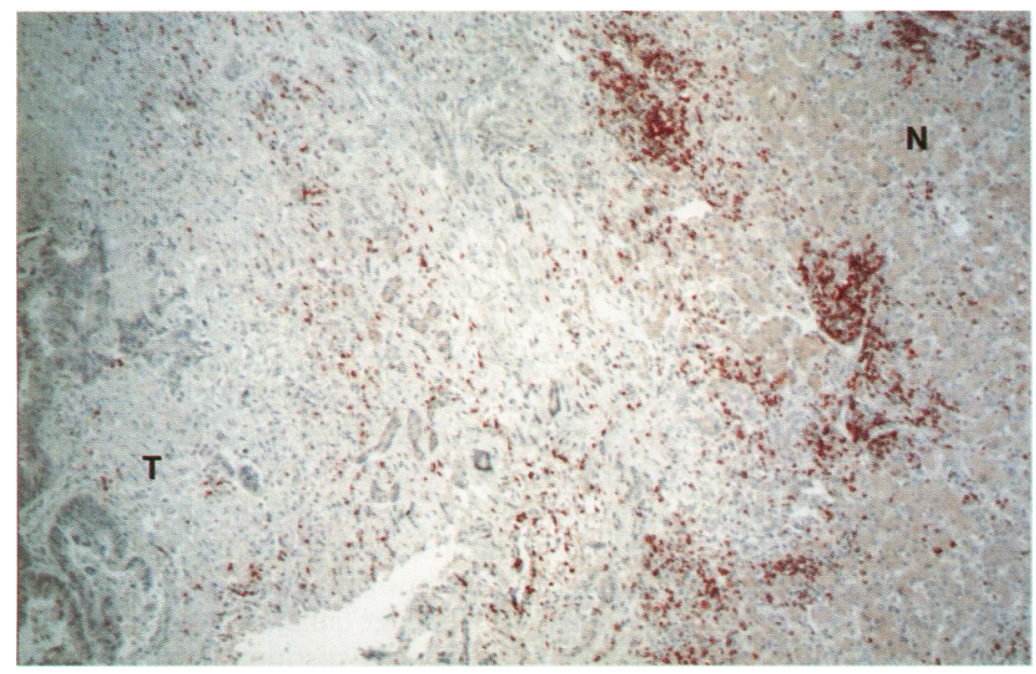

Figure 2 A section of human colorectal hepatic metastasis showing intense $C D 3+T$ cell infiltration around the tumour margin. $N=$ non-tumoral liver tissue; $T=$ tumour.

primary and secondary liver tumours, ${ }^{29}$ central nervous system tumours, ${ }^{30}$ and squamous cell carcinoma of the head and neck. ${ }^{31}$ The isolation and subsequent expansion of TIL is a labour intensive procedure which presents logistical problems for the development of TIL for clinical use (see later). TIL can be isolated from resected tumour tissue or, if sufficient material is available, from biopsy specimens. Several methods of TIL isolation utilising mechanical and enzymatic processing of tumour tissue have been described, ${ }^{32-34}$ although some groups ${ }^{35}{ }^{36}$ omit the enzymatic digestion stage and use tumour chunks to initiate TIL culture. Using tumour chunks involves less manipulation and preserves tissue architecture which may enhance TIL growth. Following enzymatic digestion, mononuclear and tumour cells are separated from the tumour digest by density gradient centrifugation. A qualitative assessment of cell recovery can be guided by in situ immunohistology performed on tumour tissue sections. TIL culture is usually initiated in medium supplemented with human $A B$ serum, LAK supernatant and human recombinant IL-2. In general, lymphocytes require periodic antigen challenge to maintain specific functional reactivity as well as continued growth. Some investigators ${ }^{35}{ }^{37}$ found that periodic stimulation of TIL cultures with autologous tumour antigen enhanced long term growth and cytotoxic reactivity. In contrast, others have managed to expand TIL to therapeutic numbers without further restimulation with tumour antigens. ${ }^{2138}$

\section{Characteristics of freshly isolated TIL}

LINEAGE MARKERS ON HUMAN TIL

Phenotypic analysis by flow cytometry has demonstrated consistently that TIL derived from animal and human tumours comprise mainly CD3 $+\mathrm{T}$ cells and a variable proportion of CD3-CD56+ NK cells. However, there are differences in the composition of $\mathrm{CD} 3+$ subsets. TIL from animal tumour models are almost exclusively CD8+, whereas those from humans show a heterogeneous phenotypic profile with varying ratios of $\mathrm{CD} 4+$ and $\mathrm{CD} 8+$ cells. A preponderance of CD8+ $\mathrm{T}$ lymphocytes with a low CD4:CD8 ratio has been observed in fresh TIL isolated from metastatic melanoma, ${ }^{390}$ renal cell carcinoma, ${ }^{41}$ breast carcinoma, ${ }^{42}$ lung carcinoma, ${ }^{43}$ primary and secondary liver tumours, ${ }^{29}$ and squamous cell carcinoma of the head and neck. ${ }^{31}$ In contrast, TIL from colonic ${ }^{26}$ and ovarian ${ }^{44}$ tumours were found to be enriched in CD4+ T cells. Large granular lymphocytes expressing the CD56 antigen are usually found in small numbers in most fresh TIL populations.

\section{ACTIVATION MARKERS}

When compared with PBL, TIL show increased expression of several activation markers. A significant proportion of TIL derived from melanoma, renal cell, ovarian, and liver tumours express CD25, HLA-DR, CD45RO, and CD69 indicating that they have been activated in vivo, presumably by encounter with specific tumour antigens. ${ }^{45} 46$

\section{ADHESION MOLECULES}

Cell adhesion molecules (CAMs) play a crucial role in the interaction between immune and tumour cells. CAMs on tumour cells regulate their interactions with endothelium and extracellular matrix and determine their ability to metastasise. ${ }^{478}$ Moreover, many of the CAMs that determine tumour metastasis can be induced or upregulated by cytokines secreted by activated monocytes and lymphocytes via interactions with cytokine receptors on the tumour cells. This raises the possibility that the presence of mononuclear cell infiltrates in some tumours might, paradoxically, benefit tumour survival by promoting metastasis. This might be particularly true of breast cancer, which is the only cancer reported to have a lower incidence in immunosuppressed patients. ${ }^{49}$

In addition to their role in tumour metastasis CAMs play a crucial role in the recruitment of TIL to tumours and in their subsequent interactions with tumour cells. Lymphocyte recruitment to tissue involves sequential adhesive interactions between circulating lymphocytes and the endothelium. Initially, primary adhe- 
sion (loose tethering), mediated classically by selectins, causes the leucocyte to roll along the endothelium, where it may encounter high local concentrations of cytokines (typically chemokines) bound to proteoglycans on the endothelial surface. These proinflammatory molecules activate leucocyte integrins to bind strongly to endothelial counter-receptors, such as intercellular adhesion molecule (ICAM)-1 and vascular cell adhesion molecule-1 (VCAM-1). This brings the cell to a halt resulting in it flattening and becoming strongly adherent and, if the correct chemotactic factor is present, it will then extravasate into the surrounding tissue and migrate to the site of inflammation. ${ }^{50}$ Little is known about the interactions of TIL with tumour endothelium and, although the precise mechanisms may differ from those involved in recruitment to normal tissue, it is likely that the general principles will apply and lymphocyte migration into tumour tissue will be dependent upon the CAMs expressed on the lymphocyte cell surface and the presence of an appropriate endothelial counter-receptor on tumour vessels. In support of this there is evidence that TIL selectively express CAMs likely to be important for their migration into tumour tissue. For example, melanoma derived TIL express the cutaneous lymphocyte antigen (CLA), a ligand for E-selectin on dermal endothelium that has been proposed as a skin homing receptor for T lymphocytes. ${ }^{50}{ }^{51}$ CLA is expressed at very low levels by $\mathrm{T}$ cells derived from other tissues, suggesting that it might be important for the homing of $\mathrm{T}$ cells to skin tumours. Preliminary data from our laboratory show that TIL from primary hepatocellular carcinoma and colorectal liver metastases express high levels of lymphocyte function antigen (LFA)-1 ( $\beta 2$ integrin) and very late activation antigen (VLA)-4 ( $\beta 1$ integrin) but low levels of $\mathrm{L}$-selectin, a phenotype that might facilitate their entry into liver tissue. ${ }^{46}$

Further support for the role of specific adhesion molecules in regulating the migration of lymphocytes from the circulation into tumour come from the elegant studies of Salmi et al. They used in vitro tissue binding assays to demonstrate that $T$ cell lines from head and neck squamous cell carcinoma bound preferentially to tumour endothelium compared with normal endothelium from the same tissue. ${ }^{52}$ We have found similar data for liver tumours showing that TIL derived from hepatocellular carcinoma bind to tumour vessels on tissue sections in vitro via an endothelial adhesion molecule, vascular adhesion protein-1, that we have recently shown to support $T$ cell binding to normal liver endothelium.

\section{TIL are functionally deficient in their ability to proliferate to tumour antigens in vitro}

There is substantial evidence to indicate that freshly isolated TIL are functionally deficient in terms of their capacity to proliferate, to release cytokines and to mediate anti-tumour cytotoxicity. Several hypotheses that have been proposed to account for the impaired effector functions of fresh TIL. They include suggestions that tumours contain suppressor lymphocytes or that the tumour itself suppresses TIL cytokine release. There are conflicting data regarding the role of lymphoid suppressor cells in diminishing the proliferative capacity of TIL. Several studies detected the presence of lymphoid suppressor activity in patients with cancer of the larynx and bladder ${ }^{53}$ and in those with melanoma, ${ }^{54}$ whilst others ${ }^{55}{ }^{56}$ failed to do so. In situ hybridisation studies of cytokine gene expression revealed that while squamous cell carcinoma of the head and neck and breast carcinoma of the mucinous type had high expression of mRNA transcripts for TNF- $\alpha$, IL-2 and IFN- $\gamma$, the non-mucin secreting breast tumour and ovarian carcinoma had absent or low levels of expression. ${ }^{57}{ }^{58}$ Using RT-PCR, Gingras et $a f^{9}$ reported decreased expression of mRNA for IL-2, IL-4, IL-6, granulocyte-macrophage colony-stimulating factor (GM-CSF), and IFN- $\gamma$ in TIL freshly isolated from lung cancers and glioblastomas in comparison with activated autologous PBL. Numerous in vitro studies have been carried out to investigate the ability of TIL to release cytokines in vitro in response to autologous tumour challenge. The results are conflicting. For instance, whereas one group suggested that TIL derived from melanoma or breast cancers secreted GM-CSF, TNF- $\alpha$ and IFN- $\gamma$ when co-cultured with autologous tumour cells, ${ }^{60}$ Guilloux et $a l^{t 1}$ reported that CD4+ and CD8+ $\mathrm{T}$ cell clones derived from melanoma did not produce large amounts of IL-2, IL-4 or IFN- $\gamma$ when stimulated by autologous tumour cells. The recent extension of the $\mathrm{T}$ helper 1 (Th1) and Th2 paradigm of functional CD4 subsets into the CD8 lineage suggests that complex subsets of functionally distinct $T$ cells may be present within tumours. However, whether these subsets develop as a consequence of the aberrant lymphocyte activation, or whether their functional activity determines it, is unclear at the moment.

There is evidence that an intrinsic lymphocyte defect in the antigen dependent activation pathway may be responsible for the impaired effector functions often seen in fresh TIL. Limiting dilution analysis showed a reduction in the frequency of proliferative $T$ cell precursors which could not be reversed by the addition of autologous tumour cells. ${ }^{32}$ Miescher et al found that fresh TIL in low density culture did not proliferate in response to stimulation by low dose IL-2, mitogens such as phytohaemagglutinin, or cross linking the TCR with anti-CD3 monoclonal antibody. ${ }^{556}$

\section{TIL show defective tumour cytotoxicity in vitro}

$\mathrm{T}$ cell cytotoxicity is mediated by at least two distinct mechanisms: namely, perforin dependent induction of membrane lysis and Fas induced DNA fragmentation and apoptosis. $^{62-65}$ Fas (APO-1, CD95) is a cell surface molecule that can mediate both apoptotic cell death of transformed cells and co-stimulatory signal transduction. It has been proposed that signalling through Fas upregulates the early 
Table 1 Abnormalities of $T$ cell signal transduction in malignancy

\begin{tabular}{|c|c|c|}
\hline Tumour type & Signalling defect & Source of $T$ cells \\
\hline $\begin{array}{l}\text { Murine colonic and renal } \\
\text { carcinoma }^{68}\end{array}$ & 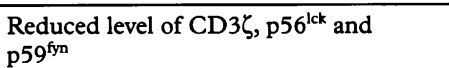 & Spleen \\
\hline Murine fibrosarcoma ${ }^{69}$ & $\begin{array}{l}\text { Reduced level of } \mathrm{CD} 3 \zeta, \mathrm{p} 56^{\text {lck }} \text { and } \\
\mathrm{p} 59^{\mathrm{fyn}}\end{array}$ & Spleen \\
\hline Human renal cell carcinoma ${ }^{70}$ & Reduced level of $\mathrm{CD} 3 \zeta$ and $\mathrm{p} 56^{\text {lck }}$ & TIL \\
\hline Human colorectal carcinoma ${ }^{71}$ & Reduced level of $\mathrm{CD} 3 \zeta$ & TIL and NK cells \\
\hline $\begin{array}{l}\text { Human renal cell, hepatic } \\
\text { metastases and head and neck } \\
\text { carcinomas }^{72}\end{array}$ & Reduced level of $\mathrm{CD} 3 \zeta$ & PBL \\
\hline Murine renal cell carcinoma ${ }^{73}$ & $\begin{array}{l}\text { NF-kB/Rel family of transcription } \\
\text { factors }\end{array}$ & Spleen \\
\hline Human renal cell carcinoma ${ }^{74}$ & $\begin{array}{l}\text { Abnormal NF- } \kappa B \text { specific DNA binding } \\
\text { activity }\end{array}$ & TIL and PBL \\
\hline
\end{tabular}

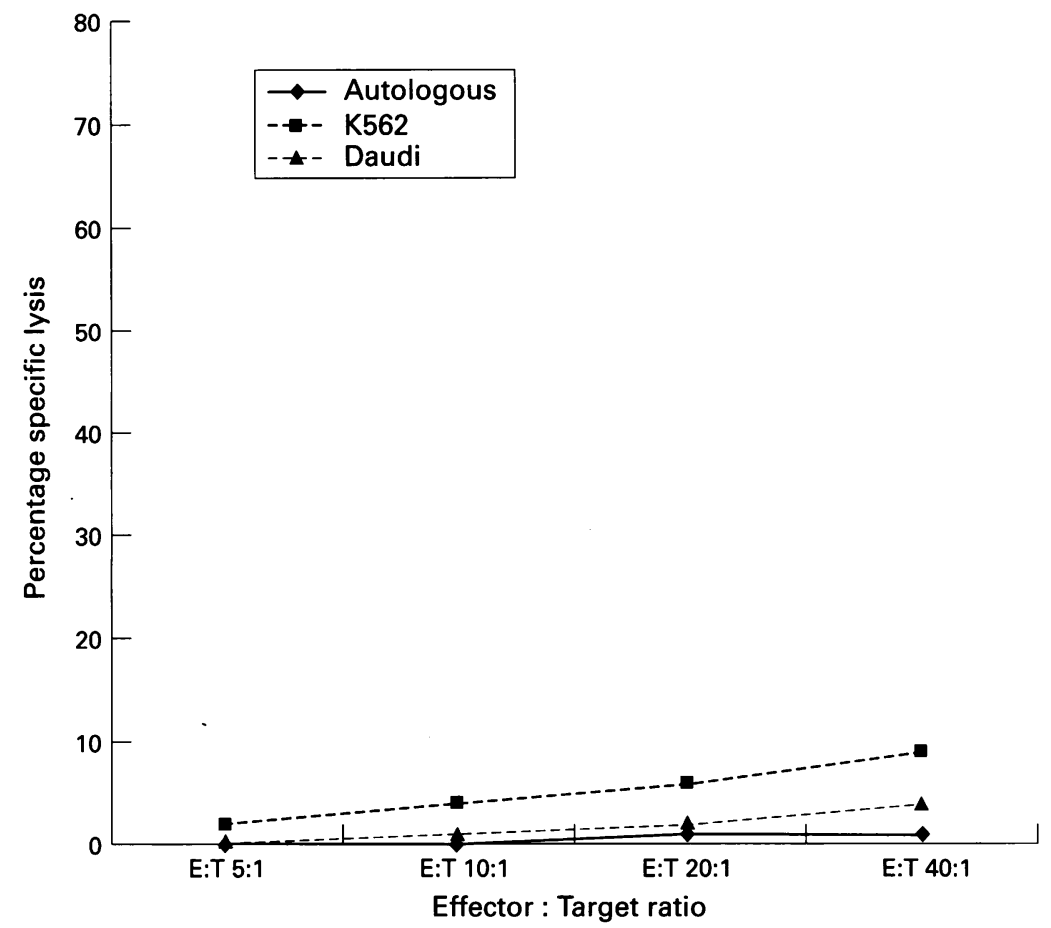

Figure 3 Cytotoxic activities of fresh (uncultured) TIL isolated from a hepatocellular carcinoma and assessed by a four hour chromium release assay against autologous, K562 and Daudi targets. functional defects often seen in fresh TIL. In general, cytotoxic $\mathrm{T}$ lymphocytes (CTL) utilise the TCR/CD3 complex to recognise antigenic peptides presented in conjunction with MHC molecules. Several studies have described major abnormalities in the structure of the TCR-CD3 complex and its associated signal transduction pathways in $\mathrm{T}$ cells of tumour bearing hosts (table 1). Splenocytes from mice bearing MCA-38 colonic carcinoma for a duration of more than 28 days showed absent or reduced expression of $\mathrm{CD} 3 \zeta, \mathrm{p} 56^{\text {lck }}, \mathrm{p} 59^{\mathrm{fym}}$ and a decreased ability to mobilise intracellular $\mathrm{Ca}^{2+}$ in response to activation signals. ${ }^{68}$ The absent expression of $\mathrm{CD} 3 \zeta$ was associated with increased levels of the Fc- $\epsilon \gamma$ chain. These changes were detected on both CD4+ and CD8+ T cells from tumour bearing mice but not in splenic $\mathrm{T}$ cells obtained from mice exposed to the same tumour for shorter durations. $\mathrm{CD} 3 \zeta$ and $\mathrm{p} 56^{\text {lck }}$ are important elements of the signal transduction mechanism for the TCR-CD3 complex. In addition, these signalling abnormalities were associated with reduced in vivo antitumour activity and in vitro effector functions of $T$ cells isolated from tumour bearing hosts. ${ }^{69}$ Similar findings were reported in $T$ cells derived from patients with renal cell ${ }^{70}$ and colorectal cancers, ${ }^{71}$ and the altered expression of $\mathrm{CD} 3 \zeta$ and $\mathrm{p} 56^{\text {lck }}$ were more pronounced in TIL than in autologous PBL. Compared with PBL from healthy controls, those from patients with colorectal hepatic metastases and squamous cell carcinoma of the head and neck were also found to have reduced levels of $\mathrm{CD} 3 \zeta .^{72}$ It is not known whether the diminished $\mathrm{CD} 3 \zeta$ expression is unique to malignant diseases or is also seen in other conditions characterised by immune deficiency. More recent studies have described abnormalities of the NF- $\mathrm{kB} /$ Rel family of transcription factors in $\mathrm{T}$ cells of tumour bearing mice $^{73}$ and patients with renal carcinoma, ${ }^{74}$ suggesting that the signalling mechanisms regulating gene transcription might be defective in tumour bearing hosts.

TCR/peptide-MHC engagement is not in itself sufficient for complete activation of $T$ cells. An additional co-stimulatory signal is required to sustain the TCR mediated activation pathway and to prevent the induction of anergy. ${ }^{756}$ It is therefore possible that defective costimulation of TIL might be responsible for their functional deficiencies. Certain cellular adhesion molecules that can provide this second activation signal include CD28, CD11a/CD18 and CD2 on $T$ cells and their respective ligands $B 7-1$ and B7-2, ICAM-1, -2 and -3 , and LFA- 3 on antigen presenting cells. The CD28/B7 pathway is particularly important for preventing the induction of anergy and the absence of B7 expression in some tumours has been proposed as a mechanism for the incomplete activation of $T$ cells and the subsequent failure of the host immune system to mount an effective anti-tumour response in vivo. ${ }^{77}$ These observations have led to studies in which tumour cells are transfected with B7-1 to enhance their immunogenicity. Such studies have been successful in animals but so far have not been extended to clinical trials. ${ }^{78}$ 
A recent study reported an absence of transferrin receptor ( $T f R$ ) expression associated with low levels of mRNA transcripts in TIL derived from renal cell carcinoma. ${ }^{79}$ As the uptake of transferrin is essential for initiating $T$ cell proliferation, ${ }^{80}$ the failure to express TfR may be another intrinsic defect of TIL that might explain their diminished proliferative capacity compared with PBL.

Although the nature and source of the factors responsible for inducing these functional deficits in TIL are not known, the available evidence suggests that they are related to the local tumour environment. Further support for this hypothesis comes from the identification of tumour derived factors including soluble secreted factors, such as cytokine transforming growth factor- $\beta,{ }^{81}$ prostaglandins, ${ }^{82}$ p15E retrovirus related glycoprotein, ${ }^{83}$ and cell surface gangliosides ${ }^{84}$ that are capable of suppressing host immune function.

TCR V gene expression in human TIL Analysis of TCR V gene usage by T cells infiltrating tumours has been used to detect tumour specific immune responses in vivo. This is based on the assumption that accumulations of $T$ cells that recognise and respond to tumour associated antigens will display a restricted pattern of TCR V gene expression. Quantitative RT-PCR is used to determine the percentage gene expression of each $V \alpha$ and $V \beta$ region and a ratio of greater than 1.8-2.0 when compared with autologous PBL is considered to be significant. When autologous PBL are not available, values outside the mean +2 SD established for each $V \alpha$ and $V \beta$ region using PBL of normal controls are deemed to indicate significant overexpression of the corresponding gene. Nitta et al ${ }^{85}$ were the first group to report the preferential expression of V $\alpha 7$ in fresh TIL of primary uveal melanomas and subsequent studies by the same group described oligoclonal $T$ cells with a restricted $V \alpha$ and V $\beta$ TCR repertoire infiltrating other primary melanomas, medulloblastomas and gliomas. ${ }^{86}$ More recent studies have used quantitative techniques to confirm the restricted TCR gene expression in a variety of tumours, including primary and metastatic melanomas, ${ }^{10}{ }^{87}$ basal cell carcinoma, ${ }^{9}$ squamous cell carcinoma of the head and neck, ${ }^{88}$ hepatocellular carcinoma, ${ }^{89}$ renal cell carcinoma, ${ }^{90}$ ovarian cancer, ${ }^{8}$ and gliomas. ${ }^{91}$ Although a restricted TCR repertoire has been found in many tumours, the restriction pattern varied between patients with the same type of tumour, suggesting either that TIL from different patients recognise and respond to different tumour antigens or that the same tumour associated antigen can be presented in different ways by MHC. In the majority of the early studies, neither the relevant antigenic epitope nor the MHC restricting element was known. Subsequent studies $^{92}$ carried out on patients with melanoma matched for HLA-A2 found that V $\beta 14$ was expressed preferentially in all of the tumours studied. $\mathrm{V} \beta 14$ overexpression was not detected in melanomas of HLA-A2 negative patients and was tumour specific as it was not found in autologous normal skin. The interpretation of TCR analysis on T cells infiltrating tumour tissue has to take into account that comparison with normal autologous tissue is important as several studies have shown that preferential expression of certain $\mathrm{V}$ gene groups occur in specific tissues, such as the skin $^{93}$ and the gut. ${ }^{94}$ Furthermore, variations in $\mathrm{V} \alpha$ and $\mathrm{V} \beta$ subfamilies have been reported in primary and secondary lesions of the same patient and differences were also observed in metastases that developed during tumour progression..$^{10}$ This may be explained by a change in tumour phenotype with respect to loss of HLA class I expression or loss of antigenic epitope that has been observed in the progression of some tumours.

The demonstration of restricted TCR expression in tumours does not provide direct evidence to correlate certain TCR subfamilies with tumour specific $T$ cell responses. The functional significance of restricted TCR expression in TIL was investigated by Mackensen et $a l^{95}$ who generated HLA-B14 restricted $\mathrm{T}$ cell clones with tumour specific cytotoxicity from a regressing melanoma lesion. That the $V \beta 16$ gene was highly expressed in both the in vitro $T$ cell clone and the in situ TIL suggested that clonal $\mathrm{T}$ cells bearing this particular TCR were responsible for mediating tumour regression in this instance. Another group ${ }^{96}$ have also demonstrated the same restricted TCR expression in tumour specific $T$ cell clones and fresh TIL of a patient with melanoma. Together these studies suggest strongly that the accumulation of clonal $\mathrm{T}$ cells in melanomas occurs and in some cases, may play an important role in tumour specific immunity.

\section{The role of $\mathrm{CD} 4+T$ cells in anti-tumour response}

Recent evidence obtained form animal studies suggests that CD4+ $\mathrm{T}$ cells are just as important CD8 $+\mathrm{T}$ cells in the development of a successful anti-tumour immune response..$^{97} 98$ Activated CD4+ $T$ cells can be classified into two functional types based on their profile of cytokine production. ${ }^{99}{ }^{100}$ Th1 cells produce IL- 2 , IFN- $\gamma$ and TNF- $\alpha$, and a functional consequence of their activation is the promotion of a cellular immune response that is associated with IgG2a production and macrophage activation. Th2 cells are characterised by IL- 4 IL-5, IL-6, IL-10, and IL-13 production and the development of selected humoral responses associated with IgG1 and IgE expression, and eosinophil and mast cell activation. $T$ cell clones producing various combinations of $\mathrm{Th} 1$ and Th2 cytokines are designated ThO. ${ }^{101} \mathrm{~A}$ functional consequence of the cytokines secreted by one subset is the suppression of activity in the other subset. There is evidence that these cytokines have important roles in mediating anti-tumour immune responses by regulating the induction and effector mechanisms of immune cells. In some animal tumour models, the Th1 cytokine profile is associated 


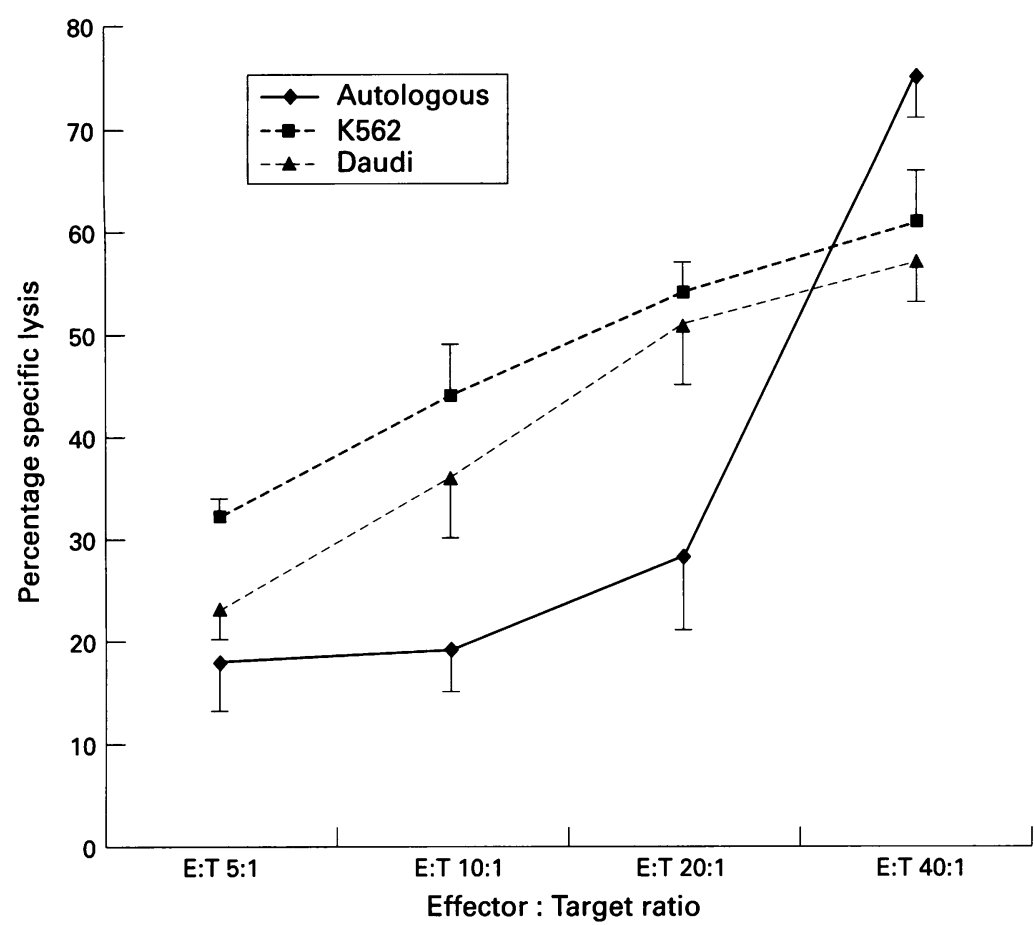

Figure 4 Cytotoxic characteristics of TIL from the same tumour specimen following three weeks of culture in 1000 IU rIL-2.

with complete tumour regression and a successful recall response to subsequent tumour challenge. ${ }^{102}$ Conversely, Ghosh et al ${ }^{103}$ demonstrated that splenic $T$ cells from renal cell cancer bearing mice lose the Th1 phenotype with progressive tumour growth and reverted to the Th1 phenotype when successfully treated with IL-2 and flavone 8-acetic acid.

IL-12 is a recently described cytokine which has wide ranging immunoregulatory activities, such as augmenting the cytotoxic capacity of and production of IFN- $\gamma$ by activated $\mathrm{NK}$ and $T$ cells and inducing the differentiation of naive Th cells to the Th1 phenotype. ${ }^{104}$ The role of IL-12 in mediating tumour regression in vivo was investigated recently by Fallarino et $a l^{105}$ in a series of experiments using P1.HTR and P198 tumour models which are normally rejected by $33 \%$ and $100 \%$ of mice, respectively. The neutralisation of endogenous IL-12 by antisera inhibited the production of IFN- $\gamma$ by $T$ cells isolated from lymph nodes of P1.HTR tumour bearing mice and prevented tumour rejection. In another group of mice bearing P198, a highly immunogenic tumour variant which is normally rejected by the majority of inoculated mice, tumour progression was observed in all mice treated with antiIL-12. Further support for the protective role of IL-12 was provided by the observations that the administration of exogenous IL-12 following tumour inoculation resulted in more than $90 \%$ of mice rejecting the P1.HTR tumour.

\section{Functional characteristics of cytokine modulated TIL}

The functional deficiencies of freshly isolated TIL can be reversed by the presence of high concentrations $(6000 \mathrm{IU} / \mathrm{ml})$ of $\mathrm{IL}-2$ in the culture medium (fig 4). This encourages the selective outgrowth of CD25+ lymphocyte subsets with enhanced proliferative and anti- tumour cytotoxic properties. The use of high concentrations of exogenous IL-2 tends to generate effector cells with a broad spectrum of cytotoxicity. Using cell sorting techniques on TIL derived from squamous cell carcinoma of the head and neck and ovarian tumours cultured in high doses of IL-2, Heo et $a l^{4} 106$ found that the effector cells responsible for cytotoxicity were CD3-CD56+ NK cells and CD3+CD56+ MHC unrestricted $\mathrm{T}$ cells. Thus, activation of TIL in vitro with high concentrations of IL-2 tends to generate nonspecific anti-tumour effectors with similar phenotypic and cytotoxic characteristics to LAK cells. Topalian et $a l^{\beta 8}$ reported two important observations regarding effector phenotype and the nature of anti-tumour cytotoxicity in melanoma TIL: that cytotoxicity against allogeneic targets was mediated mainly by $\mathrm{CD} 56+$ cells while lysis of specific autologous tumour cells was mediated by a subpopulation of cells with the CD3+CD8+ phenotype. CD8+ CTL have been generated consistently from melanoma TIL ${ }^{21}$ but less frequently from other tumours. Tagaki et $a l^{29}$ reported CD4+ mediated tumour specific effector function in TIL derived from primary liver tumours. However, TIL from other tumours tend to display non-specific anti-tumour activity mediated by a combination of CD3-CD56+ NK cells and CD3+CD56+ MHC unrestricted $\mathrm{T}$ cells (ovarian, ${ }^{24}$ colonic ${ }^{107}$ and renal cell carcino$\operatorname{mas}^{108}$ ). The nature of effector cells generated from TIL will depend not only on the characteristics of the TIL in vivo but also on the particular phenotypes that are encouraged to grow by the in vitro culture conditions. It is therefore important to analyse carefully the TIL generated by a particular culture protocol as this will determine the phenotype and hence the function of the cultured cells. Various studies have demonstrated that tumour specific CTL against ovarian, ${ }^{109}$ a liver metastasis of gastric cancer $^{110}$ and renal cell carcinoma ${ }^{111}$ could be expanded more consistently by lower doses (100-600 IU/ml) of IL-2. Thus, sufficient IL-2 should be used to overcome the failure of TIL proliferation but the use of excessive IL-2 should be avoided as this results in a loss of specificity in the TIL generated.

A variety of other cytokines have been used to activate TIL with the aim of defining optimal in vitro conditions for selecting the outgrowth and expansion of CD8+ CTL. The use of IL-4, IL- 6 or IL-7 in conjunction with IL-2 was reported to enhance the proliferative capacity of TIL derived from renal cell carcinoma but not change their cytotoxic characteristics. ${ }^{12-114}$ The combination of IL-2 and IL-4 $4^{115}$ or IL- $6^{116}$ has been shown to augment the expansion of TIL specific for autologous melanoma. In primary liver tumours ${ }^{117}$ a combination of TNF- $\alpha$ and IL-2 was more effective than IL-2 alone in generating CD8+ effectors with enhanced cytotoxicity against autologous tumour cells, but greatly reduced activity against allogeneic, K562 and Daudi targets. Furthermore, the addition of IFN- $\gamma$ to TNF- $\alpha$ plus IL-2 resulted in enhanced cytotoxicity for both autologous and 
Table 2 Tumour associated antigenic epitopes in human malignancies

\begin{tabular}{|c|c|c|c|c|}
\hline Antigen & $\underset{\text { restriction }}{M H C}$ & $\begin{array}{l}\text { Antigenic } \\
\text { peptide/structure }\end{array}$ & $\begin{array}{l}\text { Distribution in } \\
\text { normal tissue }\end{array}$ & Source of CTL \\
\hline MAGE-1 ${ }^{122}$ & A1 Cw16 & $\begin{array}{l}\text { EADPTGHSY } \\
\text { SAYGEPRKL }\end{array}$ & Testes & PBL \\
\hline MAGE-3 $3^{123}$ & A1 & EVDPIGHLY & Testes & PBL \\
\hline Tyrosinase $^{123125}$ & $\begin{array}{l}\text { A2 A24 } \\
\text { DR4 }\end{array}$ & $\begin{array}{l}\text { MLLAVLYCL } \\
\text { YMNGTMSQV }\end{array}$ & Melanocytes & TIL and PBL \\
\hline gp100/pMel-1 $7^{126127}$ & A2 & $\begin{array}{l}\text { YLEPGPVTA } \\
\text { LLDGTATLRL }\end{array}$ & Melanocytes & TIL \\
\hline $\begin{array}{l}\text { MART-1/Melan-A } \\
\text { gp } 75 / \text { TRP-1 } \\
\text { BAGE } \\
\text { GAGE }^{138}\end{array}$ & $\begin{array}{l}\text { A2 } \\
\text { A31 } \\
\text { Cw16 } \\
\text { Cw6 }\end{array}$ & AAGIGILTV & $\begin{array}{l}\text { Melanocytes } \\
\text { Melanocytes } \\
\text { Testes } \\
\text { Testes }\end{array}$ & $\begin{array}{l}\text { TIL and PBL } \\
\text { TIL } \\
\text { PBL } \\
\text { PBL }\end{array}$ \\
\hline MUC-1 139140 & None & $\begin{array}{l}\text { Underglycosylated } \\
\text { mucin }\end{array}$ & & \\
\hline
\end{tabular}

LAK sensitive tumour targets with no change in phenotypic composition or proliferative capacity. Similar findings have been reported by the same investigators for TIL obtained from ovarian carcinoma. ${ }^{117}$

\section{TIL recognition of tumour associated antigens}

$\mathrm{T}$ lymphocytes utilise the TCR/CD3 complex to recognise foreign antigens in association with MHC (in man the human leucocyte antigens or HLA). Class I MHC antigens (HLA-A, B and C) are found in all nucleated cells and serve as target structures predominantly for CD8+ $\mathrm{T}$ cells when modified by endogenously processed foreign proteins. Class II antigens (HLA-DP, DR and DQ) are expressed on activated lymphocytes and antigen presenting cells, including $B$ cells, dendritic cells and monocyte/macrophage cells. They present exogenous antigen that has been processed by antigen presenting cells predominantly to CD4+ T cells.

Most antigens recognised by $\mathrm{T}$ lymphocytes are short peptides (9-14 amino acids) bound to MHC molecules. These peptides are produced by the degradation of proteins inside the antigen presenting cell. ${ }^{118} \mathrm{~T}$ cells which recognise and respond to tumour cells in an MHC restricted manner have been generated from either TIL or PBL of patients with melanoma, ${ }^{38}{ }^{119}{ }^{120}$ squamous cell carcinoma of the head and neck, ${ }^{121}$ liver metastasis of a gastric carcinoma, ${ }^{110}$ and ovarian tumours. ${ }^{109}$ The demonstration that the specific reactivity of CTL can be inhibited by monoclonal antibodies against the TCR and MHC molecules provides strong evidence that recognition of tumour cells is both TCR mediated and MHC restricted. The search for MHC associated peptides that are selectively expressed on tumour cells and that act as epitopes for tumour specific CTL is an area of intense current interest because of the exciting potential of therapeutic anti-tumour vaccination. Melanoma associated peptide epitopes encoded by MAGE-1, ${ }^{122}$ MAGE- $3,{ }^{123}$ tyrosinase, ${ }^{124}{ }^{125}$ gp100, ${ }^{126} 127$ MART-1, ${ }^{128}{ }^{129} /$ Melan-A, ${ }^{130}$ and gp7 ${ }^{131}$ have been identified (table 2). The first peptide epitope for a human tumour was identified by Van der Bruggen et $\mathrm{l}^{122}$ using CTL clones to screen transfected cDNA libraries. A gene identified as MAGE-1 encodes the tumour antigen MZ2-E in association with HLA-A1 on a human melanoma cell line. This gene is ex- pressed in $20-40 \%$ of tumours of several different histological types, including melanoma, breast cancer, non-small cell lung cancer, squamous cell carcinoma of the head and neck, and bladder cancer. ${ }^{132}$ The same group identified a second gene, MAGE-3, that encodes a HLA-A1 restricted peptide epitope recognised by autologous CTL from a patient with melanoma. ${ }^{123}$ The peptides encoded both by MAGE-1 and -3 are highly homologous and are not expressed in normal tissues except the human testis.

Other peptide epitopes on human melanoma cells are products of genes expressed in a tissue specific, rather than a tumour specific, manner and are restricted by HLA-A2. Tyrosinase is a transmembrane glycoprotein involved in the enzymatic conversion of tyrosine during melanin synthesis. The tyrosinase gene encodes two distinct epitopes recognised by two different melanoma specific CTL clones. ${ }^{124}{ }^{125}$ The tyrosinase derived epitopes are also recognised by HLA-A24 restricted CTL6 $6^{133}$ and MHC class II restricted CD4+ Th cells. ${ }^{134}$ The fact that the same antigen encodes both class I and II restricted epitopes would seem to enhance the interaction between CD4+ Th cells and CD8+ CTL, as recent studies suggest that the antitumour cytolytic response of CTL may be facilitated by Th cells. ${ }^{135}$ A gene, designated MART$1^{128}{ }^{129}$ or Melan-A ${ }^{130}$ that encodes a HLA-A2 restricted epitope on melanoma cells, was identified independently by two different groups. The function of the protein is unknown, but it seems to be a tissue differentiation antigen expressed in melanocytes, the retina and most melanomas. This epitope is particularly important because it is recognised by anti-melanoma CTL lines from 11 of 12 different patients. ${ }^{129}$ An epitope derived from gp $100^{126} 127$ was identified by a HLA-A2 restricted CTL line generated from a patient with melanoma who was treated successfully with adoptive immunotherapy using TIL. Furthermore, gp100 was recognised by CTL lines from other patients with melanoma who had responded to TIL therapy. Another gene that has recently been shown to code for a melanoma antigen is gp75, also known as tyrosinase related protein (TRP-1). ${ }^{131} \mathrm{Gp} 75$, which was originally identified as an antigen recognised by serum IgG antibodies in a patient with melanoma, ${ }^{136} 137$ is an enzyme involved in melanin synthesis and therefore expressed in human melanocytic cells and most melanomas. The presence of CTL and IgG antibodies directed against gp75 in some patients with melanoma suggests that both the cellular and humoral arms of the immune response have been activated in vivo.

All the above antigenic epitopes are presented to T cells by MHC molecules; however, non-MHC restricted tumour specific CTL have been generated against mucin molecules in human breast and pancreatic carcinomas. ${ }^{139} 140$ The tumour associated mucins consist of underglycosylated repeating subunits that are immunogenic and presented to CTL without the need for HLA molecules.

The MAGE antigens are probably developmental antigens reexpressed during the process of carcinogenesis. Unfortunately, only about 
Table 3 Clinical results of TIL immunotherapy in patients with metastatic cancer

\begin{tabular}{|c|c|c|c|}
\hline Reference & Tumour type & Number of patients & Response rates * \\
\hline Rosenberg et al $^{142} \dagger$ & Melanoma & 86 & $34 \%$ \\
\hline \multirow[t]{3}{*}{ Kradin et $a^{143} \ddagger$} & Melanoma & 13 & $23 \%$ \\
\hline & Renal cell cancer & 7 & $29 \%$ \\
\hline & Lung cancer & 8 & 0 \\
\hline Dillman et $a l^{144} \ddagger$ & Melanoma & 21 & $21 \%$ \\
\hline Ravaud et al ${ }^{147}$ & Melanoma & 9 & 0 \\
\hline Bukowski et al ${ }^{148}$ & Renal cell cancer & 25 & 0 \\
\hline Kradin et al $^{149}$ & Lung cancer & 7 & 0 \\
\hline
\end{tabular}

${ }^{\star}$ Response rates include both complete and partial responses.

†Patients treated with TIL and IL-2 with or without cyclophosphamide.

¥IL-2 administered in conjunction with TIL.

$10 \%$ of patients with melanoma develop MAGE reactive $\mathrm{T}$ cells as only $40 \%$ of melanomas express MAGE-1 and $25 \%$ of the population in general carry the HLA-A1 allele. This suggests that vaccinating against peptides encoded by MAGE-1 is only effective in a small and selected group of patients with melanoma. In contrast, the other antigens (tyrosinase, gp100, gp75, and MART-1) represent differentiation antigens specific to normal melanocytes and melanomas. The identification of these antigens has potential therapeutic applications. They may serve as useful targets for generating tumour specific CTL for adoptive immunotherapy and also for developing tumour vaccine. However, because these differentiation antigens are also expressed in normal melanocytes, the enhancement of immune responses against such antigens runs the risk of inducing autoimmunity and damage to normal tissue. Current efforts are directed at identifying tumour antigens that possess greater immunogenicity and specificity for the purpose of generating more effective vaccines.

\section{Clinical trials of adoptive immunotherapy}

The success of adoptive immunotherapy in murine tumour models together with the development of culture techniques that permitted large scale expansion of TIL, provided the rationale for initiating this form of therapy in clinical trials. The first phase I study with TIL administered in conjunction with IL-2 and cyclophosphamide resulted in a $55 \%$ response rate in 20 patients with metastatic melanoma. ${ }^{141}$ However, when this trial concluded with a total of 86 patients the response rate was reduced to $34 \% .{ }^{142} \mathrm{~A}$ similar therapeutic response was achieved by another group ${ }^{143}$ without the concomitant administration of cyclophosphamide. The duration of therapeutic response ranged from two to 14 months. Mild side effects attributed to IL-2 were seen in some patients but no notable adverse effects were reported. However, subsequent studies failed to achieve any significant increase in objective response rate over treatment with IL-2 alone. ${ }^{144-146}$ A more recent phase I trial utilising repeated TIL infusion did not produce any objective response in nine patients with metastatic melanoma. ${ }^{147}$ Overall, the results of clinical studies conducted so far have not shown significant improvement over other immunotherapeutic modalities.

A number of factors may explain the lack of therapeutic efficacy seen in these clinical trials.
It often takes several weeks of in vitro culture to expand TIL to therapeutic numbers $\left(10^{10}\right.$ to $\left.10^{11}\right)$. Some patients, therefore, might have untreatable disease progression before treatment can be initiated. One of the main problems with TIL therapy concerns the heterogeneity and non-specific cytotoxicity of cell populations in individual TIL preparations. Perhaps the use of homogenous populations of cytotoxic TIL generated from stimulation with tumour specific peptides is one way of improving the therapeutic efficacy of TIL therapy. Furthermore, the culture conditions used for expanding TIL may be selecting the outgrowth of non-specific $T$ cells and a better definition of growth requirements for tumour specific effectors is needed. More recent studies suggest that the change in tumour phenotype that accompanies disease progression, as demonstrated by differences in TCR expression between primary and metastatic tumours and loss of MHC class I expression, may explain the lack of efficacy in adoptive TIL therapy.

Finally, there is a problem in TIL delivery to tumour sites. Most clinical studies of TIL therapy have administered large numbers of TIL into the peripheral circulation in the hope that some of them will home to tumour deposits. As mentioned above, specific adhesion molecules regulate the migration of lymphocytes from the circulation into tumour tissue and the expression of these molecules may be lost during TIL culture and expansion. Furthermore, we have shown that cultured TIL express functionally activated integrins that are likely to promote their adhesion to low flow vascular beds, such as the liver, spleen and lungs. ${ }^{46}{ }^{51}$ Clinical studies have confirmed the inefficiency of TIL delivery. A study of patients with melanoma who had received Indium-111 labelled TIL confirmed that TIL localise to tumour sites but also showed that the vast majority of infused cells become trapped in the lungs, spleen and liver. ${ }^{150}$ It is possible that manipulation of the culture conditions for TIL expansion will result in the development of TIL that retain their in vivo homing potential and are therefore more efficiently localised to tumour sites when infused into patients. Table 3 summarises these results.

\section{Future directions in TIL development}

There is considerable evidence that a specific anti-tumour immune response exists in many murine and human tumours. In the past, studies of human anti-tumour immunity have concentrated on $\mathrm{CD} 8+\mathrm{T}$ cell activities, but recent animal studies have demonstrated that optimal host immune responses require both $\mathrm{CD} 4+$ and CD8+ $T$ cell subsets. It is unclear whether each can act independently as anti-tumour effectors as both subsets have been shown to mediate specific tumoricidal activity. A greater understanding of their interaction might enhance the generation of effector cells.

Better definition of growth requirements is necessary for selecting the expansion of specific subpopulations of TIL for functional characterisation so that we can generate homo- 
geneous populations of effector cells with specific anti-tumour activity. Although a variety of cytokine combinations have been used to enhance the activity and expansion of $T$ cells in culture, they are insufficient for selecting the outgrowth of tumour specific effector cells. It seems that regular stimulation by relevant antigens presented appropriately to $\mathrm{T}$ cells is required to maintain specific tumour cytotoxicity in long term cultures. The identification of tumour associated antigens will facilitate this process in two ways. Firstly, the development of synthetic peptides derived from tumour associated antigens may obviate the need for large quantities of tumour cells for antigenic restimulation of TIL. Secondly, these peptides could be used to generate tumour specific CTL from the peripheral blood, a more readily available source of effector cells. Furthermore, synthetic peptides generated from these antigens could be developed for use in anti-tumour vaccines. Such studies are designed to promote the in vivo development of an anti-tumour immune response and are currently being investigated in patients with cancer.

The efficacy of TIL might be improved either by more selective culture conditions or by artificially enhancing TIL function by genetic manipulation. The transduction of effector cells with relevant cytokine genes for TNF, INF- $\alpha$ and $-\gamma$ and IL-2 receptor may permit the production of TIL with enhanced effector functions for use in therapeutic trials. ${ }^{151} 152$ Similar genetic approaches are also being used to manipulate tumour cells in order to increase their immunogenicity and susceptibility to killing by effector cells. The administration of IFN- $\gamma$ transduced tumour cells results in a cytokine mediated upregulation of MHC class I expression by tumour cells, thereby improving presentation of tumour associated antigens to immune cells. The use of IL-2 transduced tumour cells leads to a high local concentration of IL-2, which enhances TIL activation and effector functions. Already, the use of cytokine transduced tumour vaccines has been effective in animal models and phase I clinical trials are in progress.

The mechanisms of tumour derived immunosuppression need to be understood more clearly. If the tumour derived factors were known, strategies to inhibit their release could be designed, thereby enhancing TIL activation and efficacy. Although high concentrations of IL-2 can overcome the functional deficiencies of fresh TIL from human tumours, the end result of long term culture often leads to the generation of effector populations with nonspecific anti-tumour cytotoxicity. A greater understanding of the ways in which tumours subvert the mechanisms of $\mathrm{T}$ cell signalling will facilitate the development of the next generation of cancer immunotherapies.

$\mathrm{K}$ F Yoong is supported by a research fellowship from BUPA/Royal College of Surgeons of England.

1 Nathanson L Spontaneous regression of malignant melanoma: A review of the literature on incidence, clinical features and possible mechanisms. Conference on Spontaneous Regression of Cancer. Natl Cancer Inst Monogr neous Regression
2 Bodurtha AJ. Spontaneous regression of malignant melanoma. In: Clark WH Jr, Goldman LI, Mastrangelo MJ, eds. Human malignant melanoma. New York: Grune and Stratton, 1979:227-41.

3 Underwood JCE. Lymphoreticular infiltration in human tumours: prognostic and biological implication: A review. Br 7 Cancer 1974;30:538-48.

4 Svennevig JL, Lunde OC, Holter J, Bjorgsvik D. Lymphoid infiltration and prognosis in colorectal carcinoma. $\mathrm{Br} f$ Cancer 1984;49:375-7.

5 Wolf GT, Hudson JL, Peterson KA, Miller HL, McClatchey $\mathrm{KD}$. Lymphocyte subpopulations infiltrating squamous cell carcinomas of the head and neck: correlations with extent of tumor and prognosis. Otol Head Neck Surg 1986;95: 142-52.

6 Penn I. Tumours arising in organ transplant recipients. $A d v$ Cancer Res 1978;28:31-61.

7 Ho M, Jaffe R, Miller G, Breinig MK, Dummer JS Makowka L, et al. The frequency of Epstein-Barr virus infection and associated lymphoproliferative disorders after transplantation and its manifestations in children. Transplantation 1988;45:719-27.

8 Yamamoto K, Masuko K, Takahashi S, et al. Accumulations of distinct $\mathrm{T}$ cell clonotypes in human solid tumours. $\mathcal{F}$ Immunol 1995;154:1804-9.

9 Ohmen JD, Moy RL, Zovich D, et al. Selective accumulations of $\mathrm{T}$ cell receptor $\mathrm{V}-\beta$ gene usage in skin cancer. $\mathcal{F}$ Invest Dermatol 1994;6:751-7.

10 Scholler J, Straten PT, Birck A, et al. Analysis of T cel receptor $\alpha-\beta$ variability in lymphocytes infiltrating melanoma primary tumours and metastatic lesions. Cancer Immunol Immunother 1994;39:239-48.

11 Witte ON, Boon T. Cancer: Editorial overview. Curr Opin Immunol 1995;7:657-8.

12 Morgan DA, Ruscetti FW, Gallo RG. Selective in vivo growth of $T$ lymphocytes from normal bone marrow. Science 1976;193:1007-8.

13 Smith KA. Interleukin-2: Inception, impact and implications. Science 1988;240:1169-76.

14 Yron I, Wood TA, Speiss PJ, Rosenberg SA. In vitro growth of murine $T$ cells: The isolation and growth of lymphoid cells infiltrating syngeneic solid tumours. F Immunol 1980 125:238-45.

15 Lotze MT, Line BR, Mathisen DJ, Rosenberg SA. The in vivo distribution of autologous human and murine lymphoid cells grown in $\mathrm{T}$ cell factor (TCGF): Implicalymphoid cells grown in T cell factor (TCGF): Implications for the adoptive

16 Rosenberg SA, Spiess P, Lafreniere R. A new approach to the adoptive immunotherapy of cancer with tumour infiltrating lymphocytes. Science 1986;233:1318-21.

17 Spiess PJ, Yang JC, Rosenberg SA. In vivo antitumour activity of tumour infiltrating lymphocytes expanded in recombinant interleukin-2. F Natl Cancer Inst 1987;79:1067-75.

18 Barth RJ Jr, Bock SN, Mule JJ, Rosenberg SA. Unique murine tumour associated antigens identified by tumour infiltrating lymphocytes. F Immunol 1990;144:1531-7.

19 Barth RJ Jr, Mule JJ, Spiess PJ, Rosenberg SA. Interferon gamma and tumour necrosis factor have a role in tumour regression mediated by murine CD8+ tumour infiltrating lymphocytes. I Exp Med 1991;173:647-58.

20 Barth RJ, Mule JJ, Asher AL, et al. Identification of unique tumour associated antigens by tumour infiltrating lymphocytes using tumour specific secretion of interferon phocytes using tumour specific secretion of interferon gamma and tumo

21 Muul LM, Spiess PJ, Director EP, Rosenberg SA Identification of specific cytolytic immune response against autologous tumor in humans bearing malignan melanoma. F Immunol 1987;138:989-95.

22 Itoh $\mathrm{K}$, Tilden $\mathrm{AB}$, Balch $\mathrm{CM}$. Interleukin-2 activation of cytotoxic $\mathrm{T}$ lymphocytes infiltrating into human metastatic melanomas. Cancer Res 1986;46:3011-17.

23 Finke JH, Rayman $\mathrm{P}, \mathrm{Hart} \mathrm{L}$ et al Characterisation of tumour infiltrating lymphocyte subsets from human renal cell carcinoma-specific reactivity defined by cytotoxicity, interferon gamma secretion and proliferation. F Immunother 1994;15:91-104

24 Heo DS, Whiteside TL, Kanbour A, Herberman RB. Lymphocytes infiltrating human ovarian tumours: Role of Leu-19 (NKH1) positive recombinant IL-2-activated cultures of lymphocyte infiltrating human ovarian tumours. Immunol 1988;140:4042-9.

25 Kooi S, Freedman RS, Rodriguezvillanueva J, et al. Cytokine production by $T$ cell lines derived from tumour infiltrating lymphocytes from patients with ovarian infiltrating lymphocytes from patients with ovarian carcinoma: Tumour-specific immune responses and inhibition of antigen-independent cytokine production by 429-37.

26 Wimmenauer S, Keller H, Rahner S, et al. Phenotypical and functional characteristics of tumour infiltrating lymphocytes from colon carcinomas stimulated with rIL-2 an rIL-4 in vitro: Comparison with lymphocytes of the normal colon mucosa and the peripheral blood. Anticancer Res 1994;14:963-8.

27 Whiteside TL, Miescher S, Hurlimann J, Moretta L, von Fliedner V. Clonal analysis and in situ characterisation of lymphocytes infiltrating human breast carcinomas. Cancer Immunol Immunother 1986;23:169-78.

28 Kurnick JT, Kradin RL, Blumberg R, et al. Functional characterisation of $T$ lymphocytes propagated from lung carcinoma. Clin Immunol Immunopathol 1986;38:367-80. 
29 Tagaki S, Chen K, Schwartz R, et al. Functional and phenotypic analysis of tumour infiltrating lymphocytes isolated from human primary and metastatic liver tumours and cultured in recombinant interleukin-2. Cancer 1989;63: 102-11.

30 Kuppner MC, Hamou MF, de Tribolet N. Immunohistological and functional analyses of lymphoid infiltrates in

31 Synderman CH, Heo DS, Chen K, Whiteside TL, Johnson $\mathrm{JT}$. T cell in tumour infiltrating lymphocytes of head and neck cancer. Head Neck 1989;11:331-6.

32 Whiteside TL, Miescher S, Hurlimann J, Moretta L, von Fliedner V. Separation, phenotyping and limiting dilution analysis of lymphocytes infiltrating human solid tumors. In f Cancer 1986;37:803-11.

33 Whiteside TL, Miescher S, MacDonald RH, von Fliedner V. Separation of tumour infiltrating lymphocytes from tumor cells in human solid tumors: A comparison between velocity sedimentation and discontinous density gradients. $f$ Immunol Methods 1986;90:221-33.

34 Yannelli JR. The preparation of effector cells for use in the adoptive cellular immunotherapy of human cancer. $\mathcal{F}$ Immunol Methods 1991;139:1-16.

35 Maleckar JR, Friddell CS, Sferruzza A, et al. Activation and expansion of tumour-derived activated cells for therapeutic use. F Natl Cancer Inst 1989;81:1655-60.

36 Kradin RL, Boyle LA, Preffer FI, et al. Tumour-derived interleukin-2 dependent lymphocytes in adoptive immunotherapy of lung cancer. Cancer Immunol Immunother therapy of lun

37 Skornick Y, Topalian S, Rosenberg SA. Comparative studies of the long term growth of lymphocytes from tumour infil trates, tumour draining lymph nodes and peripheral blood by repeated in vitro stimulation with autologous tumour. $\mathscr{f}$ Biol Resp Modif 1990;9:431-8

38 Topalian SL, Soloman D, Rosenberg SA. Tumour-specific lysis by lymphocytes infiltrating melanomas. $f$ Immunol 1989;142:3714-25.

39 Itoh K, Platsoucas CD, Balch CM. Autologous tumourspecific cytotoxic lymphocytes in the infiltrate of human metastatic melanomas. Activation by interleukin-2 and metastatic melanomas. Activation by interleukin-2 and autologous tumour cells and involvem

40 Cardi G, Mastrangelo MJ, Berd D. Deletion of T cells with the CD4+ CD45RA+ phenotype in lymphocytes that infiltrate subcutaneous metastases of human melanoma. Cancer Res 1989;49:6562-5.

41 Finke JH, Tubbs R, Connely B, et al. Tumour infiltrating lymphocytes in patients with renal cell carcinoma. Ann $N Y$ Acad Sci 1988;532:387-94.

42 Bilik R, Mor C, Hazaz B, et al. Characterisation of T lymphocyte subpopulations infiltrating primary breast can cer. Cancer Immunol Immunother 1989;28:144-7.

43 Rabinowich $\mathrm{H}$, Cohen R, Bruderman L, et al. Functional analysis of mononuclear cells infiltrating into tumours: Lysis of autologous human tumour cells by cultured infiltrating lymphocytes. Cancer Res 1987;47:173-7.

44 Freedman RS, Tomasovic B, Templin S, et al. Large scale expansion in interleukin-2 of tumour-infiltrating lymphocytes from patients with ovarian carcinoma for adoptive immunotherapy. F Immunol Methods 1994;167:145-60.

45 Whiteside T. Tumour infiltrating lymphocytes as antitumour effector cells. Biotherapy 1992;5:47-61.

46 Yoong KF, Williams A, Hubscher SG, et al. Expression of endothelial adhesion molecules and T-cell homing recep-
tors in human hepatic tumors [abstract]. FASEB $f$ tors in human

47 Weiss L. Cell adhesion molecules-a critical examination of their role in metastasis. Invas Metast 1994;14:192-7.

48 Tang DG, Honn KV. Adhesion molecules and tumour metastasis - an update. Invas Metast 1994;14:109-22.

49 Stewart T, Tsai SCJ, Grayson H, et al. Incidence of de-novo breast cancer in women chronically immunosuppressed after organ transplantation. Lancet 1995;346:796-8.

50 Adams DH, Shaw S. Leucocyte-endothelial interaction and regulation of leucocyte migration. Lancet 1994;343: $831-6$

51 Adams DH, Yannelli J, Newman W, et al. Adhesion of tumour-infiltrating lymphocytes to endothelium: A phenotypic and functional analysis [abstract]. Immunolog 1994;83:10.

52 Salmi M, Grenman R, Grenman S, et al. Tumour endothelium selectively supports the binding of IL-2 propagated tumour-infiltrating lymphocytes. F Immunol 1995;154: 6002-12.

53 Cozzolino F, Torcia M, Carossino AM, et al. Characterisation of cells from invaded lymph nodes in patients with solid tumours. Lymphokine requirement for tumourspecific lymphoproliferative response. $\mathcal{f}$ Exp Med 1987;166: 303-18.

54 Mukherji B, Wilhelm SA, Guha A, et al. Regulation of cellular immune response against autologous human melanoma. Evidence for cell-mediated suppression of in vivo immune response. $\mathcal{F}$ Immunol 1986;136: 1888-92.

55 Miescher S, Stoeck M, Whiteside TL, et al. Altered activation pathways in $\mathrm{T}$ lymphocytes infiltrating human solid tumours. Transplant Proc 1988;20:344-6.

56 Miescher S, Stoeck M, Qiao L, et al. Proliferative and cytolytic potentials of purified human tumour infiltrating $T$ lymphocytes. Impaired response to mitogen-driven stimulation despite $T$ cell receptor expression. Int $¥$ Cancer 1988 ; 42:659-66.

57 Vitolo D, Zerbe T, Kanbour A, et al. Expression of mRNA for cytokines in tumour-infiltrating mononuclear cells in ovarian adenocarcinoma and invasive breast cancer. Int $\mathcal{F}$ Cancer 1992;51:573-80.

58 Vitolo D, Letessier EM, Johnson JT, et al. Immunologic effector cells in head and neck cancer. $\mathcal{F}$ Natl Cancer Inst 1992;13:203-11.

59 Gingras MC, Roussel E, Roth JA, et al. Little expression of cytokine mRNA by fresh tumour-infiltrating mononuclear leucocytes from glioma and lung adenocarcinoma. Cytokine 1995;7:580-8.

60 Schwartzentruber DJ, Topalian SL, Mancini MJ, et al. Specific release of granulocyte-macrophage colony-stimulating factor, tumour necrosis factor- $\alpha$, and IFN-gamma by human tumour infiltrating lymphocytes after autologous tumour stimulation. F Immunol 1991;146: 153-64.

61 Guilloux Y, Viret C, Gervois N, et al. Defective lymphokine production by most CD8+ and CD4+ tumour-specific $\mathrm{T}$ cell clones derived from human melanoma-infiltrating lymphocytes in response to autologous tumour cells in vitro. phocytes in response to autologo

62 Kagi D, Ledermann B, Burki K, et al. Cytotoxicity mediated by $T$ cells and natural killer cells is greatly impaired in perforin deficient mice. Nature 1994;369:31-7.

63 Rouvier E, Luciani MF, Golstein P. Fas involvement in $\mathrm{Ca}^{2+}$-independent $\mathrm{T}$ cell-mediated cytotoxicity. $\mathcal{F}$ Exp Med 1993;177:195-200.

64 Suda T, Takahashi T, Golstein P, et al. Molecular cloning and expression of the fas ligand, a novel member of the tumour necrosis factor family. Cell 1993;75:1169-78.

65 Kagi D, Vignaux F, Ledermann B, et al. Fas and perforin pathways as major mechanisms of T cell-mediated cytotoxicity. Science 1994;265:528-30.

66 Miescher S, Whiteside TL, Carrel S, et al. Functional properties of tumour infiltrating and blood lymphocytes in patients with solid tumours: effects of tumour cells and their supernatants on proliferative responses of lymphocytes. F Immunol 1986;136:1899-907.

67 Ostenstad B, Sioud M, Schlichting E, et al. Freshly isolated tumour infiltrating lymphocytes have a high cytotoxic potential, as measured by their ability to induce apoptosis in the target cell. Scand f Immunol 1995;41:42-8

68 Mizoguchi H, O'Shea J, Longo DL, et al. Alterations in signal transduction molecules in T-lymphocytes from tumourbearing mice. Science 1992;258:1795-8.

69 Loeffler CM, Smyth MJ, Longo DL, et al. Immunoregulation in cancer-bearing hosts: Downregulation of gene expression and cytotoxic function in CD8 $+\mathrm{T}$ cells. $\mathcal{f}$ Immunol 1992;149:949-56.

70 Finke JH, Zea AH, Stanley J, et al. Loss of T-cell receptor $\zeta$ chain in T-cells infiltrating human renal cell carcinoma. Cancer Res 1993;53:5613-16.

71 Nakagomi H, Petersson M, Magnusson I, et al. Decreased expression of the signal-transducing $\zeta$ chains in tumorexpression of the signal-transducing $\zeta$ chains in tumorinfiltrating T-cells and NK cells of patients

72 Farace F, Angevin E, Vanderplancke J, et al. The decreased reversed by IL -2 administration. Int $\mathcal{F}$ Cancer 1994;59:752-5.

73 Ghosh P, Sica A, Young HA, et al. Alterations in NF-Kappa$B /$ Rel family proteins in splenic $T$ cells from tumourbearing mice and reversal following therapy. Cancer Res 1994;54:2969-72

74 Wang $\mathrm{Q}$ Stanley J, Kudoh S, et al. T cell infiltrating non-Hodgkin's lymphoma show altered tyrosine phosphorylation pattern even though $T$ cell receptor $C D 3$ associated kinases are present. F Immunol 1995;155: 1382-92.

75 Schwartz RH. A cell culture model for T lymphocyte clonal anergy. Science 1990;248:1349-55.

76 Van Seventer GA, Shimizu Y, Shaw S. Role of multiple accessory molecules in T-cell activation. Curr Opin Immunol 1991;3:294-303.

77 Chen L, McGowan P, Ashe S, et al. Tumor immunogenecity determines the effect of B7 costimulation on T-cellmediated tumor immunity. $f$ Exp Med 1994;179:523-32.

78 Allison JP, Hurwitz AA, Leach DR. Manipulation of costimulatory signals to enhance antitumor T-cell responses. Curr Opin Immunol 1995;7:682-6.

79 Kudoh S, Stanley J, Edinger M, et al. T lymphocytes infiltrating renal cell carcinoma have a reduced expression of transferrin receptor. Int $\mathcal{F}$ Cancer 1994;58:369-75.

80 Neckers LM, Cossman J. Transferrin receptor induction in mitogen-stimulated human $\mathrm{T}$ lymphocytes is required for DNA synthesis and cell division and is regulated by interleukin-2. Proc Natl Acad Sci USA 1983;80:3494-8.

81 Wrann M, Bodmer S, de Martin R, et al. T cell suppressor factor from human glioblastoma cells is a $12.5 \mathrm{Kd}$ protein closely related to transforming growth factor $\beta$. EMBO $f$ 1987;6: 1633-6.

82 Botha JH, Robinson KM, Ramchurren N, et al. Human oesophageal carcinoma cell lines: Prostaglandin production, biologic properties and behaviour in nude mice. $\mathcal{F}$ Nat Cancer Inst 1986;76:1053-6.

83 Cianciolo GJ, Copeland TD, Oroszlan S, Synderman R. Inhibition of lymphocyte proliferation by synthetic peptide homologous to retroviral envelope proteins. Science 1985 230:453-5

84 Robb RJ. The suppressive effect of gangliosides upon IL-2 dependent proliferation as a function of inhibition of IL-2 receptor association. F Immunol 1986;136:971-6.

85 Nitta T, Oksenberg JR, Rao RA, et al. Predominant expression of $T$ cell receptor $V$ alpha 7 in tumour-infiltrating lymphocytes of uveal melanoma. Science 1990;249:672-4.

86 Nitta T, Sato K, Okumura K, et al. An analysis of T cell receptor variable region genes in tumour-infiltrating 
lymphocytes within malignant tumours. Int $\mathcal{F}$ Cancer 1991 49:545-50

87 Weidmann E, Elder EM, Trucco $\mathrm{M}$, et al. Usage of $\mathrm{T}$ cell receptor $\mathrm{V}$ beta chain genes in fresh and cultured tumourinfiltrating lymphocytes from human melanoma. Int $7 \mathrm{Can}$ cer 1993;54:383-90.

88 Yasumura S, Weidmann E, Hirabayashi $\mathrm{H}$, et al. HLA restriction and $T$ cell receptor $V \beta$ gene expression of cytotoxic $\mathrm{T}$ lymphocytes reactive with human squamous cell carcinoma of the head and neck. Int $\mathcal{f}$ Cancer 1994;57 297-305.

89 Weidmann E, Whiteside TL, Giorda R, et al. The T cell receptor $\mathrm{V}$ beta gene usage in tumour-infiltrating lymphocytes and blood of patients with hepatocellular phocytes and blood of patients with

90 Mitropoulos D, Kooi S, Rodriguezvillanueva J, et al. Characterization of fresh (uncultured) tumour-infiltrating lymphocytes and TIL-derived T cell lines from patients with renal cell carcinoma. Clin Exp Immunol 1994;97:3217.

91 Ebato $M$, Nitta $T$, Yagita $H$, et al. Shared amino acid sequences in the ND-beta- $\mathrm{N}$ and $\mathrm{N}$-alpha regions of the $\mathrm{T}$ cell receptor of tumour-infiltrating lymphocytes within malignant glioma. Eur f Immunol 1994;24:2987-92.

92 Salvi S, Segalla F, Rao S, et al. Overexpression of T cell receptor beta chain variable region TCRBV14 in HLA-A2-
matched primary human melanoma. Cancer Res 1995;55: 3374-9.

$93 \mathrm{Sim}$ GK. Intraepithelial lymphocytes and the immune system. Adv Immunol 1995;58:297-343.

94 Ikeda H, Sato N, Matsuura A, et al. Analysis of T cell receptor $\mathrm{V}$ region gene usage of cytotoxic $\mathrm{T}$ lymphocytes and tumour-infiltrating lymphocytes derived from human autologous gastric signet ring cell carcinomas. Cancer Res 1993;53:3078-84.

95 Mackensen A, Ferradini L, Carcelain G, et al. Evidence for in situ amplification of cytotoxic $T$ lymphocytes with antitumour activity in a human regressive melanoma. Cancer Res 1993;53:3569-73.

96 Weidmann E, Logan TF, Yasumura S, et al. Evidence fo oligoclonal T-cell response in a metastasis of renal cell carcinoma responding to vaccination with autologous tumour cells and transfer of in vitro-sensitized vaccine-drainin lymph node lymphocytes. Cancer Res 1993;53:4745-7.

97 Dranoff G, Jaffee E, Lazenby A, et al. Vaccination with irradiated tumour cells engineered to secrete murine granulocyte-macrophage colony stimulating factor stimugranulocyte-macrophage colony stimulating factor stimulates potent, specific and long lasting antitum
Proc Natl Acad Sci USA 1993;90:3539-43.

98 Huang AYC, Golumbek P, Ahmadzadeh M, et al. Role of bone marrow-derived cells in presenting MHC class I-restricted tumour antigens. Science 1994;264:961-5.

99 Mosmann TR, Cherwinski H, Bond MW, et al. Two types of murine helper $\mathrm{T}$ cell clone-definition according to profiles of lymphokine activities and secreted proteins. $\mathcal{f}$ Immunol 1986;136:2348-57.

100 Mosmann TR, Coffman RL. TH1 and TH2 cells: different patterns of lymphokine secretion lead to different functional properties. Annu Rev Immunol 1989;7:145-73.

101 Street NE, Schumacher TA, Fong H, et al. Heterogeneit of mouse helper $\mathrm{T}$ cell: evidence from bulk cultures and limiting dilution cloning for precursors of Th1 and Th2 cells. F Immunol 1990;144:1629-39.

102 McAdam AJ, Pulaski BA, Harkins SS, et al. Synergistic effects of coexpression of the Th1 cytokines IL-2 and IFNgamma on generation of murine tumour reactive cytotoxic gamma on generation of murine tum. Int 7 Cancer 1995;61:628-34.

103 Ghosh P, Komschlies KL, Cippitelli M, et al. Gradual loss of T-helper 1 populations in spleen of mice during progressive tumour growth. 7 Natl Cancer Inst 1995;87:1478-83. 104 Hsieh CS, Macatonia SE, Tripp CS, et al. Development of
Th1 CD4+ cells through IL-12 produced by Listeriainfected macrophages. Science 1993;260:547-9.

105 Fallarino F, Uyttenhove C, Boon T, et al. Endogenous IL-12 is necessary for rejection of P815 tumour variants in vivo. FImmunol 1996;1 156:1095-100.

106 Heo DS, Whiteside TL, Johnson JT, et al. Long term interleukin-2 dependent growth and cytotoxic activity of tumour-infiltrating lymphocytes from human squamous cell carcinomas of the head and neck. Cancer Res 1987;47: 6353-62.

107 Yoo YK, Heo DS, Hata K, et al. Tumour infiltrating lymphocytes from human colon carcinomas. Functional and phenotypic characteristics after long term culture in recombinant interleukin-2. Gastroenterology 1990;98:259-68.

108 Beldegrun A, Muul LM, Rosenberg SA. Interleukin-2 expanded tumour infiltrating lymphocytes in human renal cell cancer. Isolation, characterisation and anti-tumour cell cancer. Isolation, characterisation

109 Ioannides CG, Platsoucas CD, Rashed S, et al. Tumour cytolysis by lymphocytes infiltrating ovarian malignant cytolysis by lymphocytes infiltrating

110 Shimizu Y, Weidmann E, Iwatsuki S, et al. Characterization of human auto-tumor-reactive $T$ cell clones obtained from tumor-infiltrating lymphocytes in liver metastasis of gastric carcinoma. Cancer Res 1991;51:6153-62.

111 Koo AS, Tso CL, Shimabukuro T, et al. Autologous tumour-specific cytotoxicicty of tumour-infiltrating lymphocytes derived from human renal cell carcinoma. $\mathcal{f}$ Immunother 1991;10:347-54.

112 Tso CL, Duckett T, de Kernion JB, et al. Modulation of umour-infiltrating lymphocytes derived from human renal
113 Lee TY, Koo AS, Penret C, et al. The effects of interleukin-6 on tumour-infiltrating lymphocytes derived from human renal cell cancer. 7 Urol 1991;145:663-7.

114 Ditonno P, Tso CL, de Kernion JB, et al. Regulatory effects of interleukin-7 on renal tumour-infiltrating lymphocytes. Urol Res 1992;20:205-10.

115 Kawakami Y, Rosenberg SA, Lotze MT. Interleukin-4 promotes the growth of tumour-infiltrating lymphocytes cytotoxic for human autologous melanoma. $\mathcal{f} \operatorname{Exp}$ Med 1988;168:2183-91

116 Marcus SG, Perrylalley D, Mule JJ, et al. The use of interleukin-6 to generate tumour infiltrating lymphocytes with enhanced in vivo antitumour activity. $\mathcal{F}$ Immunother 1994;15:105-12.

117 Shimizu Y, Iwatsuki S, Herberman RB, et al. Effects of cytokines on in vitro growth of tumour-infiltrating lymphocytes obtained from human primary and metastatic lymphocytes obtained from human primary and metastatic

118 Townsend A, Bodmer H. Antigen recognition by class I-restricted T lymphocytes. Annu Rev Immunol 1989;7: 601-24.

119 Herin M, Lemoine C, Weymants $P$, et al. Production of stable cytolytic $\mathrm{T}$ cell clones directed against autologous human melanoma. Int $\mathcal{F}$ Cancer 1987;15:390-6.

120 Crowley NJ, Slingluff CL, Darrow TL, et al. Generation of human autologous melanoma-specific cytotoxic $\mathrm{T}$ cells using HLA-A2 matched allogeneic melanomas. Cancer Res 1990;50:492-8.

121 Hald J, Rasmussen N, Claesson MH. Tumour-infiltrating lymphocytes mediate lysis of autologous squamous cell carcinoma of the head and neck. Cancer Immunol carcinoma of the head and

122 Van der Bruggen P, Traversari C, Chomez P, et al. A gene encoding an antigen recognised by cytolytic $\mathrm{T}$ lymphocytes on a human melanoma. Science 1991;254:1643-7.

123 Gaugler B, van den Eynde B, van der Bruggen, et al. Human gene MAGE-3 codes for an antigen recognised on a melanoma by autologous cytolytic $\mathrm{T}$ lymphocytes. $\mathcal{F}$ Exp Med 1994:179:921-30.

124 Brichard V, Van Pel A, Wolfel T, et al. The tyrosinase gene codes for an antigen recognised by autologous cytolytic $T$ lymphocytes on HLA-A2 melanomas. F Exp Med 1993; lymphocytes

125 Wolfel T, Van Pel A, Brichard V, et al. Two tyrosinase nonapeptides recognised on HLA-A2 melanomas by autologous cytolytic T lymphocytes. Eur F Immunol 1994;24:75964.

126 Kawakami Y, Eliyahu S, Delgado $\mathrm{CH}$, et al. Identification of a human melanoma antigen recognised by tumour infiltrating lymphocytes associated with in vivo tumour rejection. Proc Natl Acad Sci USA 1994;91:6458-62.

127 Bakker AB, Schreurs MW, de Boer AJ, et al. Melanoma lineage-specific antigen gp100 is recognised by melanomaderived tumour infiltrating lymphocytes. $\mathcal{f}$ Exp Med 1994 179:1005-9.

128 Kawakami Y, Eliyahu S, Sakaguchi K, et al. Identification of the immunodominant peptides of the MART-1 human melanoma antigen recognised by the majority of HLA-A2 restricted tumour infiltrating lymphocytes. $\mathscr{f}$ Exp Med 1994;180:347-52.

129 Kawakami Y, Elihayu S, Delgado $\mathrm{CH}$, et al. Cloning of the gene coding for a shared human melanoma antigen recognised by autologous T cells infiltrating tumours. Proc Natl Acad Sci USA 1994;91:3515-19.

130 Coulie PG, Brichard V, Van Pel A, et al. A new gene encoding for a differentiation antigen recognised by autologous cytolytic $\mathrm{T}$ lymphocytes on HLA-A2 melanomas. $\mathcal{F}$ Exp Med 1994;180:35-42.

131 Wang RF, Robbins PF, Kawakami Y, et al. Identification of a gene encoding a melanoma tumour antigen recognised by Med 1995;181:799-804.

132 Zakut R, Topalian SL, Kawakami Y, et al. Differential expression of MAGE-1, -2 , and -3 messenger RNA in transformed and normal human cell lines. Cancer Res transformed

133 Robbins PF, El-Gamil M, Kawakami Y, et al. Recognition of tyrosinase by tumour infiltrating lymphocytes from a patient responding to immunotherapy. Cancer Res 1994;54: 3124-6.

134 Topalian SL, Rivoltini L, Mancini M, et al. Human CD4+ $T$ cells specifically recognise a shared melanoma-associated antigen encoded by the

$135 \mathrm{Li} \mathrm{Y,} \mathrm{McGowan} \mathrm{P,} \mathrm{Hellstrom} \mathrm{I,} \mathrm{et} \mathrm{al.} \mathrm{Costimulation} \mathrm{of}$ tumour-reactive CD4+ and CD8+ T lymphocytes by B7, a natural ligand for $\mathrm{CD} 28$, can be utilised to treat established mouse melanoma. $₹$ Immunol 1994;153:421-8.

136 Mattes MJ, Thomson TM, Old LJ, et al. A pigmentationassociated differentiation antigen of human melanoma defined by a precipitating antibody in human serum. Int $\mathcal{f}$ Cancer 1983;32:717-21.

137 Vijayasyradhi S, Bouchard BB, Houghton AN. The melanoma antigen gp75 is the human homologue to mous b (BROWN) locus gene. F Exp Med 1990;171:1375-80.

138 Boon T, Gajewski TF, Coulie PG. From defined human tumour antigens to effective immunization? Immunol Today 1995;16:334-6.

139 Barnd DL, Lan MS, Metzgar RS, et al. Specific, major histocompatibilty complexunrestricted recognition of tumour-associated mucins by human cyto

140 Jerome KR, Barnd DL, Bendt KM, et al. Cytotoxic T lymphocytes derived from patients with breast adenocarci- 
noima recognise an epitope present on the protein core of a mucin molecule preferentially expressed by malignan mucin molecule preferentially expr

141 Rosenberg SA, Packard BS, Aebersold PM, et al. Use of tumour infiltrating lymphocytes and interleukin-2 in the immunotherapy of patients with metastatic melanoma. $N$ Engl f Med 1988;319:1676-81.

142 Rosenberg SA, Yannelli JR, Yang JC, et al. Treatment of patients with metastatic melanoma with autologous tumour-infiltrating lymphocytes and interleukin-2. I Nat Cancer Inst 1994;86:1159-66.

143 Kradin RL, Kurnick JT, Lazarus DS, et al. Tumour infiltrating lymphocytes and interleukin-2 in treatment of advanced cancer. Lancet 1989;i:577-80.

144 Dillman RO, Oldham RK, Barth NM, et al. Continous interleukin-2 and tumour infiltrating lymphocytes as treatment of advanced melanoma. A national biotherapy study ment of advanced melanoma. A
group trial. Cancer 1991;68:1-8.

145 Hanson J, Petit R, Walker M, et al. Phase II study of tumour infiltrating lymphocytes (TIL) therapy with bolus recombinant interleukin-2 in metastatic melanoma [abstract]. Proc Am Soc Clin Oncol 1991;10:295.

146 Markowitz A, Parkinson D, Itoh K, et al. Phase I B study of tumour infiltrating lymphocytes (TIL) combined with recombinant interferon- $\alpha 2 A$, recombinant interleukin- 2 and cyclophosphamide in patients with advanced renal cell carcinoma and malignant melanoma [abstract]. Proc Am Soc Clin Oncol 1991;10:216.

147 Ravaud A, Legrand E, Delaunay MM, et al. A phase I trial of repeated tumour infiltrating lymphocytes (TIL) infusion in metastatic melanoma. Br f Cancer 1995;71:331-6.

148 Bukowski RM, Sharfman W, Murthy S, et al. Clinical results and characterization of tumour-infiltrating lymphocytes with or without recombinant interleukin-2 in human metastatic renal cell carcinoma. Cancer Res 1991;51:4199-205.

149 Kradin RL, Boyle LA, Preffer FI, et al. Tumour-derived interleukin-2 dependent lymphocytes in adoptive immunotherapy of lung cancer. Cancer Immunol Immunother 1987;24:76-85.

150 Pockaj BA, Sherry RM, Wei JP, et al Localisation of indium-111 labelled tumour-infiltrating lymphocytes to tumour in patients receiving adoptive immunotherapy. tumour in patients recei

151 Yamaue H, Kashmiri SVS, Defilippi R, et al. Enhanced interleukin-2 production in human tumour infiltrating lymphocytes engineered by 3 -truncated interleukin gene. $\mathcal{F}$ Immunother 1994;16:262-74.

152 Treisman J, Hwu P, Yannelli JR, et al. Up-regulation of tumour necrosis factor- $\alpha$ production by retrovirally transduced human tumour infiltrating lymphoc retinoic acid. Cell Immunol 1994;156:448-57. 